\title{
Analysis and simulation of a single buoy mooring system based on sea environment
}

- Le Xuan Quang

- Vo Hien

- Nguyen Huu Huy

Ho Chi Minh City University of Transport

- Tran Ly Minh Nhat

- Nguyen Toan Thang

- Do Quang Khanh

- Nguyen Tuong Long

University of Technology - VNU-HCM

(Manuscript Received on August 21 th 2014; Manuscript Revised November 11 $1^{\text {th }}$, 2014)

\section{ABSTRACT:}

Single Point Mooring (SPM) is of great use to offshore floating structures which are currently in use in Vietnam's coastal waters. However, this country is facing the lack of the related guidelines and standards for analysis, simulation and design of SPM system. This fact is the rationale for this paper which is aimed to propose a procedure for computation of the effects of sea environment on a SPM system. Specifically, the procedure

Keywords: Single point mooring, mooring chain, SPM.

\section{INTRODUCTION}

For the offshore oil and gas industry nowadays, the use of floating storage to store, process and extract crude oil is an effective solution to offshore deep-water oil fields especially ones located on marginal zones in which the construction of the above floating storage systems are more cost-effective than the pipelines. The floating production, storage and offloading (FPSO) moored to SPM system is being used more widely in Viet Nam. The safety and stability of SPM is extremely important and necessary to improve the productivity when FPSO is working. However, most of the previous researches on this issue focus on the stability of mooring lines with sinkers and without the sinkers[4], as well as on the usage of ANSYS AQWA program to simulate the motion of mooring lines[3]. Therefore, the enables the identification of maximum load exerting on the mooring buoy. Then, such identification together with the water depth parameter enables the determination of the optimal length and diameter of the desired chain. Finally, this paper presents a primary simulation of the mooring chain system according to various water depth conditions.

\section{Trang 146}

understanding of the effect of parameters on the design and simulation of mooring lines is limited, which causes difficulties for the design, inspection, and maintenance of mooring lines. Based on the foregoing reality, the authors present the theories and algorithms in the design and simulation of mooring lines. Simultaneously, according to the studied algorithms [1], we build a program by Matlab [6]to shorten the computation's time. Then, the actual hydrological parameters and FPSO data [2], [5] are used to run the program and the outputs will be examined. Finally, from the results, we will evaluate and draw conclusions about the parameters affecting the design and simulation of mooring lines. 


\section{DESCRIPTION OF PROBLEM}

The practical construction in this report is FPSO Ruby Princess, which operates in Ruby water located in block 1 and 2, offshore Vietnam, approximately $155 \mathrm{~km}$ Northeast of Vung Tau. FPSO's specification is presented in Table 1. The vessel operates at the depth of $50 \mathrm{~m}$ where the environmental variation is not extreme. It uses the SPM with the mooring chains being distributed in three different directions with equal angles. Each direction has three chains to ensure that when the vessel is working, there will be at least two or more mooring chains bearing the load. Additionally, the influences of the current, wind and tide are also taken into account, behavior of mooring under environmental loading can be seen in Figure 1. From all the mentioned factors, the authors have computed and converted them to the horizontal load on the buoy by the algorithm "Equilibrium Position" from which the maximum horizontal load on the buoy will be determined. Then, we will use the horizontal load known from the procedure to study the parameters impacting on the behavior of Buoy - Chain - Anchor such as working depth, length and diameter of chain.

The properest parameters of working depth, length and diameter of chain for Princess will be determined by assuming the horizontal load $\mathrm{H}$ the same at every point in this report. The actual chain length is also assumed to be $600 \mathrm{~m}$. The diameter of chain is $120 \mathrm{~mm}$.

Table 1. FPSO Ruby Princess' specification

\begin{tabular}{|l|l|}
\hline LOA & $.02 \mathrm{~m}$ \\
\hline LBP & $260.0 \mathrm{~m}$ \\
\hline BMLD & $43.30 \mathrm{~m}$ \\
\hline DMLD & $22.45 \mathrm{~m}$ \\
\hline DWT & $140.900 \mathrm{~T}$ \\
\hline LOADED DISPLACEMENT & $161.200 \mathrm{~T}$ \\
\hline LOAD DRAFT & $17.07 \mathrm{~m}$ \\
\hline BALLAST DISPLACEMENT & $73.000 \mathrm{~T}$ \\
\hline BALLAST DRAFT & $9.20 \mathrm{~m}$ \\
\hline
\end{tabular}

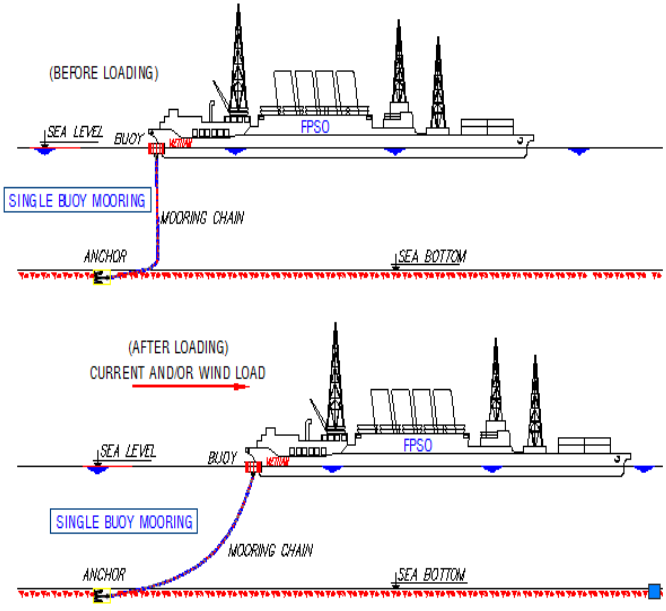

Figure. 1. Behavior of mooring under environmental loading

\section{DETERMINATION OF MAXIMUM LOAD ON SPM SYSTEM}

\subsection{Modelization of impacts on FPSO}

This section describes methods for determination of static wind and current load on single moored vessels. The horizontal load, longitudinal force, and yaw moment are evaluated. Figure 2 defines the coordinate system and nomenclature for describing these loads. The angle between the wind and the current is $\theta_{\text {wc. }}$ The wind angle, $\theta_{\mathrm{w}}$, and current angle, $\theta_{\mathrm{c}}$ are defined as positive in clockwise direction. The discussion of the various physical phenomena involve in this procedure is provided in following section.

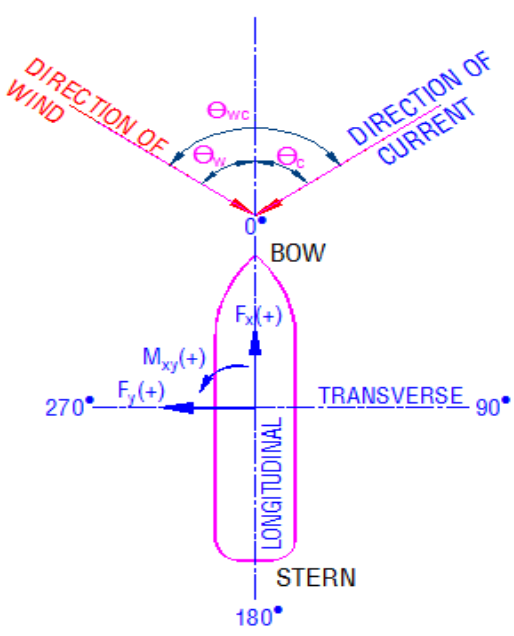

Figure. 2. Coordinate system and nomenclature for wind and current loadProcedure 
The procedure for determination of the maximum horizontal load ${ }^{l}$

- Step 1 of the procedure for determination of the maximum horizontal loads to input the hydrological and ship parameters.

- Step 2 in the process is to analyze the effective loads including the sum of the horizontal loads, the sum of the longitudinal loads, and the sum of the yaw moments on mooring elements as indicated in the following:

$$
\begin{aligned}
& F_{x T}=F_{x \mathrm{w}}+F_{x c} \\
& F_{y T}=F_{y \mathrm{w}}+F_{y c} \\
& M_{x y T}=M_{x y w}+M_{x y c}
\end{aligned}
$$

- Step 3 of the procedure is to determine the sum of moment:

$$
\sum M=M_{x y w}+M_{x y c}-F_{y T} \mathrm{AR} M
$$

If the sum of moments is not equal to zero, then start the loop from scratch with the different hydrological parameters until the total moment is zero.

- Step 4 consists of calculating the maximum horizontal load acting on buoy.

$$
H^{2}=F_{x T}^{2}+F_{y T}^{2}
$$

General procedure for determination equilibrium point of zero moment and maximum horizontal load is given in Figure 3 below

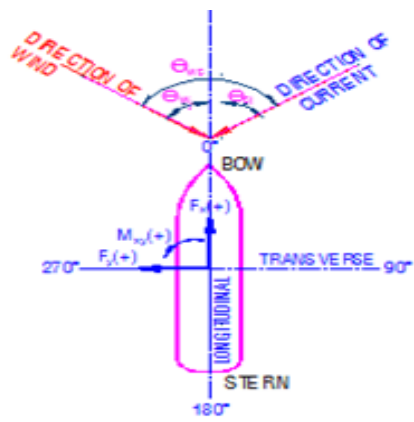

- Notes:

$\Theta_{w c}$ : the angle between the wind and the current

$\Theta_{c}$ : the current angle. $\Theta_{w}$ : the wind angle.

$\Sigma M:$ the sum of moment.

$\mathrm{H}_{\max }$ : the maximum horizontal load.

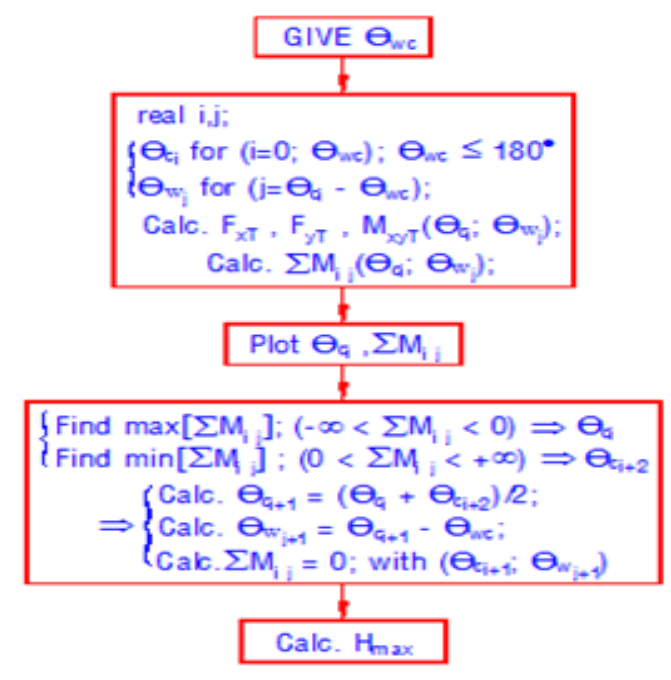

Figure. 3. Procedure for determining equilibrium point of zero moment and maximum horizontal load

\section{ANALYSIS AND SIMULATION OF MOORING CHAIN SYSTEM}

\subsection{Definition and scope of computation}

The plot describes relationship between the horizontal load, water depth and catenary parameters is represented in Figure 4.

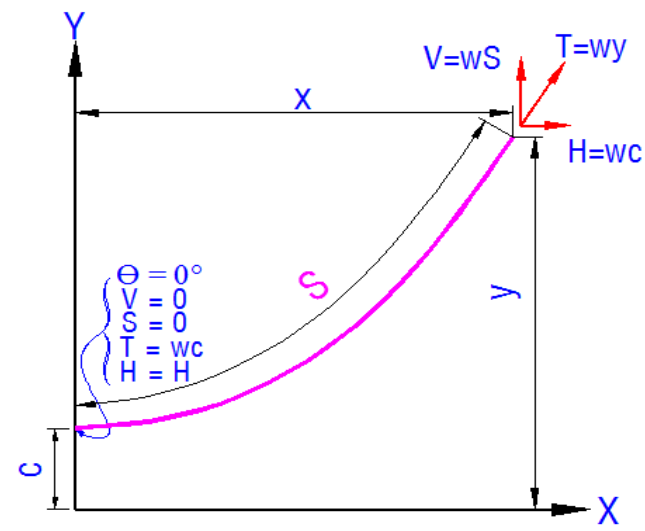

Figure 4. Definition sketch for the use of catenary analysis

At any point $(\mathrm{x}, \mathrm{y})$ the following hold:

$$
\begin{aligned}
& H=w c=T \cos \theta \\
& T=w y
\end{aligned}
$$

Where: $\mathrm{V}=$ Vertical force at point $(\mathrm{x}, \mathrm{y})$

$\mathrm{W}=$ Submerged unit weight of chain.

\section{Trang 148}


$S=$ Length of curve (chain length) from point $(0$, c) to point $(x, y)$.

$\mathrm{T}=$ Line tension at point $(\mathrm{x}, \mathrm{y})$

$\theta=$ Angle of mooring line with horizontal

$\mathrm{H}=$ Horizontal load at point $(\mathrm{x}, \mathrm{y})$

$\mathrm{C}=$ Distance from origin to $\mathrm{y}-$ intercept $=\mathrm{H} / \mathrm{w}$

- Formulas

The shape of the catenary is governed by the following:

$$
\begin{aligned}
& y^{2}=s^{2}+c^{2} \\
& y=c \cosh (x / c) \\
& s=c \sinh (x / c)
\end{aligned}
$$

Equation (*) may be more conveniently expressed as:

$$
x=c \ln \left[\frac{s}{c}+\sqrt{\left(\frac{s}{c}\right)^{2}+1}\right]
$$

Note that, in the above equations, the horizontal load on the chain is the same at every point and that all measurement of $\mathrm{x}, \mathrm{y}$, and $\mathrm{S}$ are referenced to the catenary origin.

\subsection{Procedure}

\section{The procedure for computing of catenary ${ }^{l}$}

- Step 1 of the procedure is to input parameters $\theta_{\mathrm{a}}$, $\mathrm{w}_{\mathrm{s}}, \mathrm{wd}_{\mathrm{d}}$, and $\mathrm{H}$

- Step 2 is for the distance from origin to $\mathrm{y}$ to be determined - intercept $\mathrm{c}=\mathrm{H} / \mathrm{ws}_{\mathrm{s}}$

- Step 3 in the row is to compute the height from origin to buoy, given as:

$$
y_{b}=c+w d
$$

- Step 4 in computing the catenary is to determine the chain length from anchor to buoy, expressed by:

$$
S_{a b}=\sqrt{y_{b}^{2}-c^{2}}
$$

If $S_{a b}>S_{\text {actual }}$ then increase the chain length until $S_{a b}<S_{\text {actual }}$
- Step 5, the horizontal distance from the anchor to the buoy is defined as:

$$
x_{a b}=c \cdot \ln \left[\frac{S_{a b}}{c}+\sqrt{\left(\frac{S_{a b}}{c}\right)^{2}+1}\right]
$$

- Step 6, the tension in the mooring line at the buoy is represented: $T_{b}=w s . y_{b}$

- Step 7 in the process is to compare $\mathrm{T}_{\mathrm{b}}$ with $\mathrm{T}_{\text {break }}$ and reach the conclusion about the ship condition as follows.

$$
\text { If } T_{b}<T_{\text {break }} \text { Ship is safe. }
$$

If $T_{b}>T_{\text {break }}$ Therefore, we need to calculate the working depth again to assure the ship's anchor. Numerical results NUMERICAL RESULTS

\subsection{The maximum horizontal load}

\subsubsection{Input}

FPSO's specification is presented in Table 1 and the statistics on actual hydrological parameters of direction and velocity taken at the site are given in Table 2.

Table 2. Input parameters of the hydrology

\begin{tabular}{lcccc}
\hline Direction & $\boldsymbol{\theta}_{\text {we }}$ (degrees) & $\begin{array}{c}\mathbf{V}_{\mathbf{w}} \\
(\mathbf{m} / \mathbf{s})\end{array}$ & $\mathbf{V}_{\mathbf{c}}(\mathbf{m} / \mathbf{s})$ & $\boldsymbol{\alpha}^{\mathbf{o}}\left(\mathbf{o f} \mathbf{V}_{\mathbf{c}}\right)$ \\
\hline $\mathrm{N}$ & 120 & 36.20 & 0.87 & 240 \\
\hline $\mathrm{NE}$ & 163 & 45.00 & 1.20 & 242 \\
\hline $\mathrm{E}$ & 83 & 29.10 & 0.92 & 277 \\
\hline $\mathrm{SE}$ & 94 & 19.20 & 1.54 & 41 \\
\hline $\mathrm{S}$ & 112 & 21.40 & 1.76 & 70 \\
\hline $\mathrm{SW}$ & 146 & 33.40 & 1.65 & 79 \\
\hline $\mathrm{W}$ & 172 & 32.70 & 1.60 & 78 \\
\hline $\mathrm{NW}$ & 180 & 31.80 & 1.05 & 135 \\
\hline
\end{tabular}

All $\theta$ angles are defined between 0 and 180 degrees. Use $\mathrm{V}_{\mathrm{w}}$ and $\mathrm{V}_{\mathrm{c}}$ of $45 \mathrm{~m} / \mathrm{s}$ and $1.76 \mathrm{~m} / \mathrm{s}$ respectively for all $\theta_{\mathrm{wc}}$ to determine the point of equilibrium (sum of moment is equal to zero) and corresponding horizontal loads.

\subsubsection{Plots of sum of moment}

First, the parameters are inserted to the algorithm. For each angle $\theta_{\mathrm{wc}}$, a series of total moment values and an equilibrium position of zero moment corresponding to each pair of angle $\theta_{\mathrm{c}}$ and $\theta_{\mathrm{w}}$ in the range of $\theta_{\mathrm{wc}}$ will be 
determined, then the results are presented in the following plots.

\subsubsection{Results of maximum horizontal load}

From the computation and the plot of sum of moments, $\Sigma \mathrm{M}=0$, versus $\theta_{\mathrm{c}}$ and $\theta_{\mathrm{w}}$ in the previous section, the corresponding values of maximum horizontal load $\mathrm{H}$ are determined. The results are presented in Table 3 as follows.

The maximum value of the horizontal load $\mathrm{H}$ is set at $1,144.897 \mathrm{~T}$, which is the representative horizontal load for all the wind directions and currents based on the design probability in order to compute the mooring lines in water.
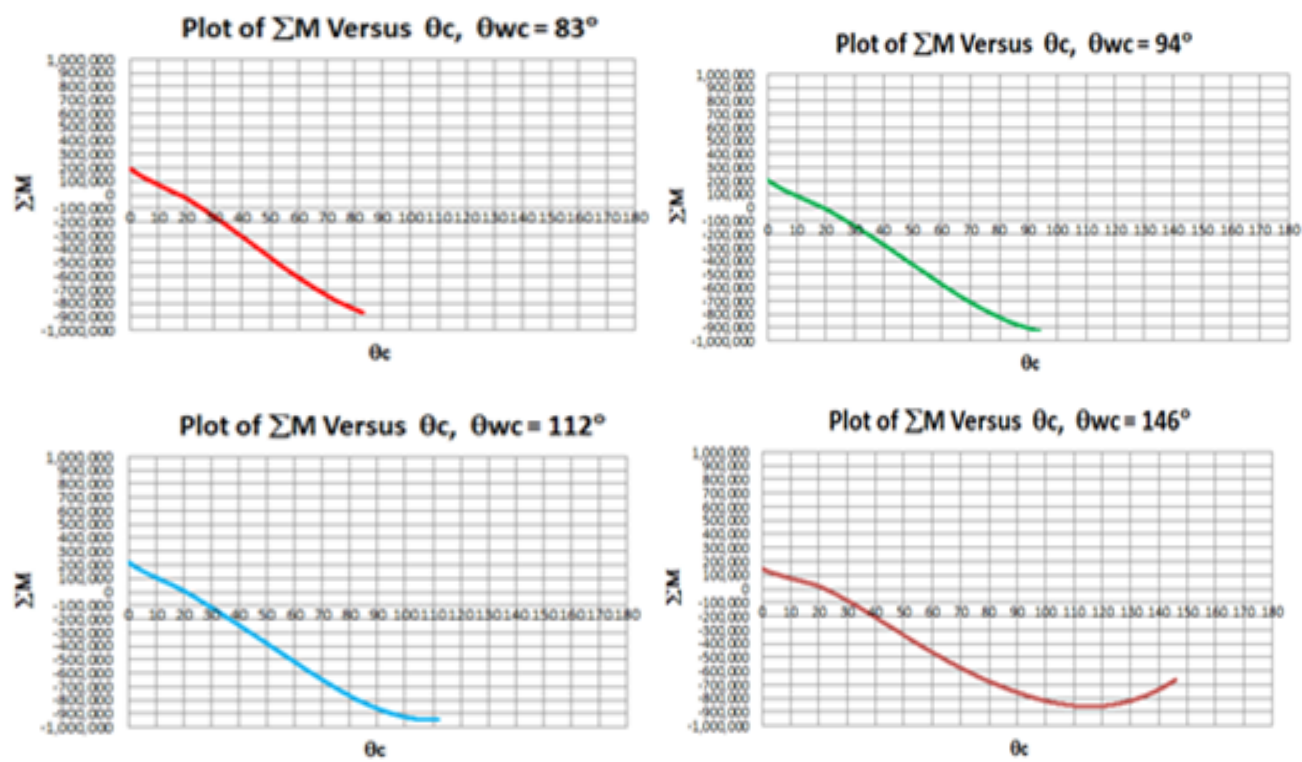

Plot of $\Sigma \mathrm{M}$ Versus $\theta \mathrm{c}, \theta w c=120^{\circ}$
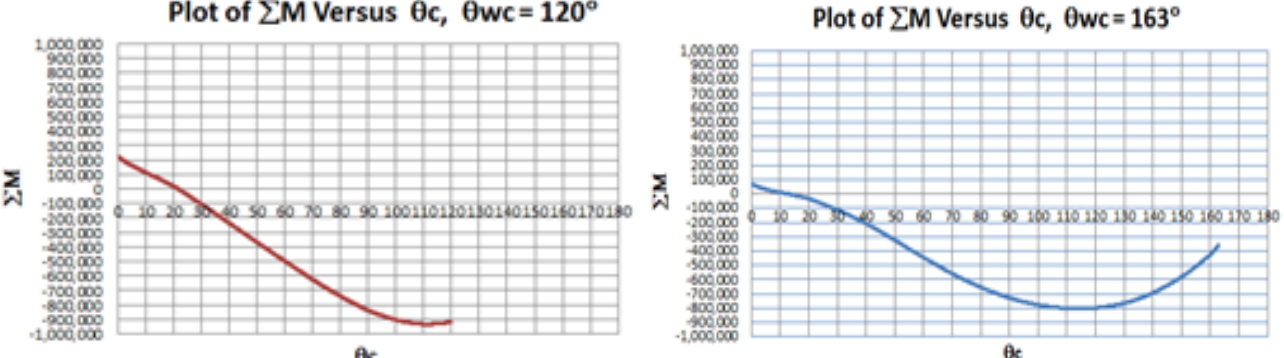

$\theta<$

$\theta<$

Plot of $\Sigma M$ Versus $\theta c, \theta w c=172^{\circ}$
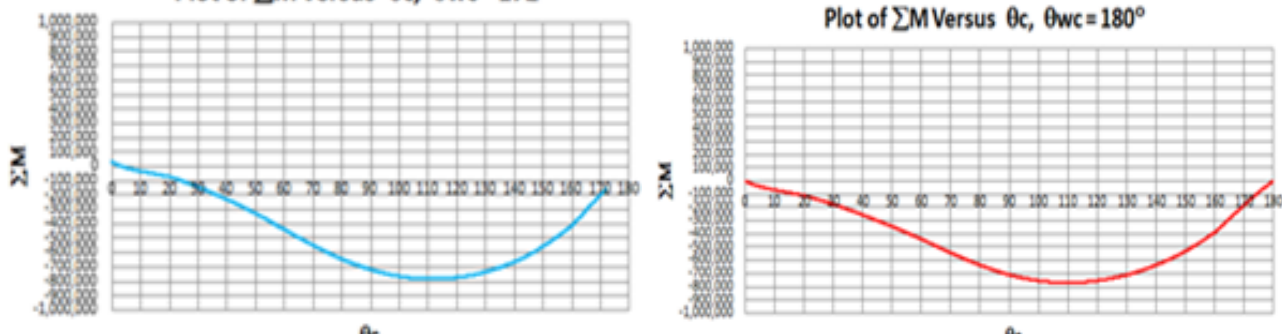

es

Figure. 5. Plots of $\sum \mathrm{M}$ vesus $\theta_{\mathrm{c}}$ and $\theta_{\mathrm{w}}$

\section{Trang $\mathbf{5 0}$}


Table 3. Results of horizontal loads

\begin{tabular}{llll}
\hline Direction & $\begin{array}{c}\boldsymbol{\theta}_{\mathrm{wc}} \\
\text { (degrees) }\end{array}$ & $\begin{array}{c}\boldsymbol{\theta}_{\mathbf{c}} \\
\text { relative to vessel } \\
\text { bow (degrees) }\end{array}$ & $\begin{array}{c}\mathbf{H} \\
\text { Horizontal load } \\
\text { (Tons) }\end{array}$ \\
\hline $\mathrm{N}$ & 120 & 21.6 & $1,089.500$ \\
$\mathrm{NE}$ & 163 & 12.6 & 786.264 \\
$\mathrm{E}$ & 83 & 17.5 & 715.803 \\
$\mathrm{SE}$ & 94 & 19.0 & 825.543 \\
$\mathrm{~S}$ & 112 & 20.8 & $1,007.831$ \\
SW & $\mathbf{1 4 6}$ & $\mathbf{2 2 . 1}$ & $\mathbf{1 , 1 4 4 . 8 9 7}$ \\
$\mathrm{W}$ & 172 & 3.6 & 188.583 \\
$\mathrm{NW}$ & 180 & 0.0 & 9.715 \\
\hline
\end{tabular}

3.5. The results of the relationship between water depth and the parameters of mooring lines

\subsubsection{Supporting computational tools}

Authors have used Matlab's program ${ }^{5}$ to simulate procedure for determining the parameters which include the length of the chain from anchor to buoy $\left(\mathrm{S}_{\mathrm{ab}}\right)$, the horizontal distance from the anchor to the buoy ( $\mathrm{xab}$ ), the tension in the mooring line at the buoy $\left(\mathrm{T}_{\mathrm{b}}\right)$, and the vertical load at the anchor $\left(\mathrm{V}_{\mathrm{a}}\right)$. From the result, we will examine the relationship between the water depth, chain length and chain section in order to make the most appropriate choices for ship operations.

\subsubsection{Input}

Input parameters consisting of Chain length, Horizontal load $(H / 3)$, Water depth $\left(\mathrm{w}_{\mathrm{d}}\right)$, and Submerged unit weight of chain $\left(\mathrm{w}_{\mathrm{s}}\right)$.
Table 4. Input parameters

\begin{tabular}{llll}
\hline Chain length $(\mathbf{m})$ & $\mathbf{H}(\mathbf{T})$ & $\mathbf{w}_{\mathbf{s}}(\mathbf{T} / \mathbf{m})$ & $\mathbf{w}_{\mathbf{d}}(\mathbf{m})$ \\
\hline 600 & 381.0 & 0.25 & 50
\end{tabular}

\subsubsection{Results}

* Results of relationship between water depth and different parameters of catenary

The water depth is varied from $50 \mathrm{~m}$ to $150 \mathrm{~m}$ to determine the largest water depth and afterwards the chain length will be estimated while ship is working at a corresponding depth water. The calculation results of the relationship between water depth and traction, chain length are shown in table 5. These values increase linearly together. The relation plots are provided in Figure 6 and 7.

Table 5. Results when the water depth changes

\begin{tabular}{lllllll}
\hline $\mathbf{W}_{\mathbf{d}}(\mathbf{m})$ & $\mathbf{5 0}$ & $\mathbf{7 0}$ & $\mathbf{9 0}$ & $\mathbf{1 1 0}$ & $\mathbf{1 3 0}$ & $\mathbf{1 5 0}$ \\
\hline $\mathrm{S}_{\mathrm{ab}}(\mathrm{m})$ & 393.740 & 467.369 & 530.723 & 589.638 & $\mathbf{6 4 3 . 0 2 1}$ & $\mathbf{6 9 2 . 9 0 7}$ \\
$\mathrm{X}_{\mathrm{ab}}(\mathrm{m})$ & 389.484 & 460.347 & 520.569 & 575.867 & 625.358 & 671.049 \\
$\mathrm{~T}_{\mathrm{b}}(\mathrm{T})$ & 393.834 & 398.832 & 403.758 & 408.834 & 413.833 & 418.835 \\
\hline
\end{tabular}

* Relationship between diameter and different parameters of catenary $y^{4}$ : At the water depth of $50 \mathrm{~m}$ and $70 \mathrm{~m}$, when the diameter of chain increases from $122 \mathrm{~mm}$ to $132 \mathrm{~mm}$, the relation between the chain - At water depth of $50 \mathrm{~m}$ : length, horizontal distance and traction is identified. The calculation results at the depth of $50 \mathrm{~m}$ and $70 \mathrm{~m}$ are indicated in Table 6 and 7, respectively.

Table 6. Results when the water depth is $50 \mathrm{~m}$

\begin{tabular}{llllll}
\hline $\mathbf{D}(\mathbf{m m})$ & $\mathbf{1 2 2}$ & $\mathbf{1 2 4}$ & $\mathbf{1 2 7}$ & $\mathbf{1 3 0}$ & $\mathbf{1 3 2}$ \\
\hline $\mathrm{S}_{\mathrm{ab}}(\mathrm{m})$ & 378.784 & 372.734 & 364.040 & 355.862 & 350.694 \\
$\mathrm{Xab}(\mathrm{m})$ & 374.376 & 368.235 & 359.449 & 351.150 & 345.922
\end{tabular}


$\begin{array}{llllll}\mathrm{T}_{\mathrm{b}}(\mathrm{T}) & 394.859 & 395.308 & 395.997 & 396.691 & 397.159\end{array}$

- At water depth of $70 \mathrm{~m}$ :

Table 7. Results when the water depth changes

to $70 \mathrm{~m}$.

\begin{tabular}{llllll}
\hline $\mathbf{D}(\mathbf{m m}$ & $\mathbf{1 2 2}$ & $\mathbf{1 2 4}$ & $\mathbf{1 2 7}$ & $\mathbf{1 3 0}$ & $\mathbf{1 3 2}$ \\
\hline $\mathrm{S}_{\mathrm{ab}}(\mathrm{m})$ & 449.7376 & 442.624 & 432.3792 & 422.712 & 416.6016 \\
$\mathrm{X}_{\mathrm{ab}}(\mathrm{m})$ & 442.4416 & 435.2064 & 424.7792 & 414.96 & 408.728 \\
$\mathrm{~T}_{\mathrm{b}}(\mathrm{T})$ & 400.2658 & 400.9008 & 401.8624 & 402.8376 & 403.4908 \\
\hline
\end{tabular}

From the results in Table 6 and 7, it can be seen that when the diameter of chain ascends, the traction is in direct proportion, whereas the chain length and horizontal distance descend. The relation plots are shown in Figure 8,9, and 10, respectively.

\subsubsection{Plots}

- Relationship between water depth and different parameters of catenary and relationship between diameter and different parameters of catenary are presented in the following figures:

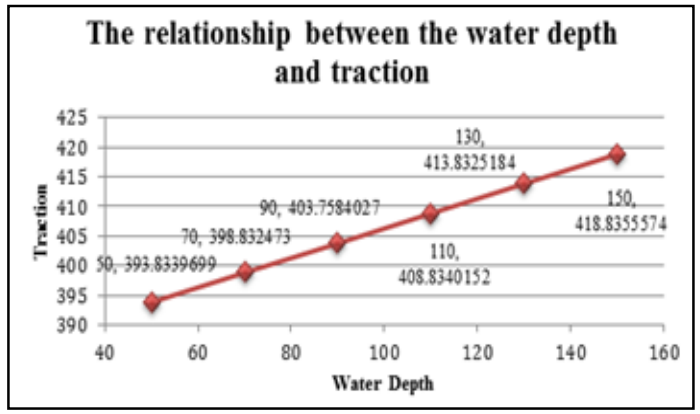

Figure. 6. The relationship between the water depth and traction

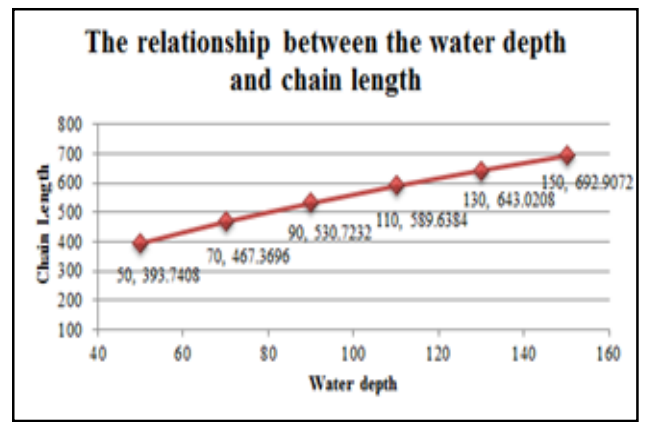

Figure. 7. The relationship between the water depth and chain length

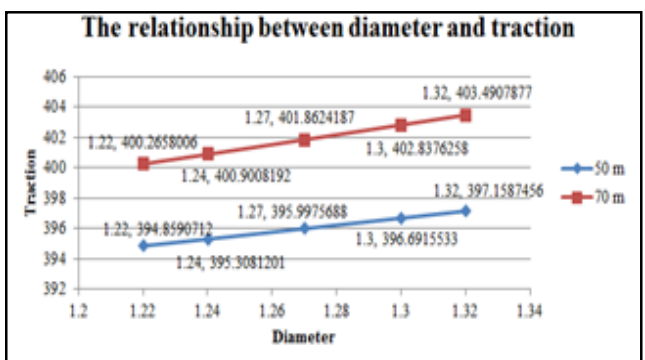

Figure. 8. The relationship between diameter and traction

\section{Trang 52}




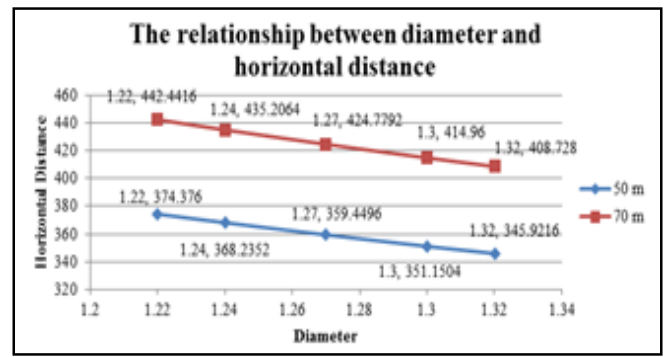

Figure. 9. The relationship between diameter and horizontal distance

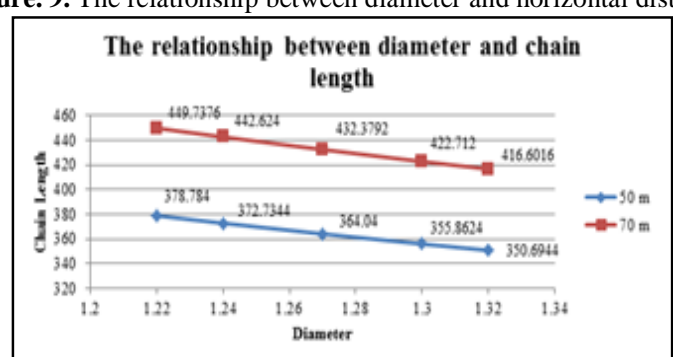

Figure. 10. The relationship between diameter and chain length

- Relationship between different horizontal load levels and horizontal distance is presented in the following Figure 11:

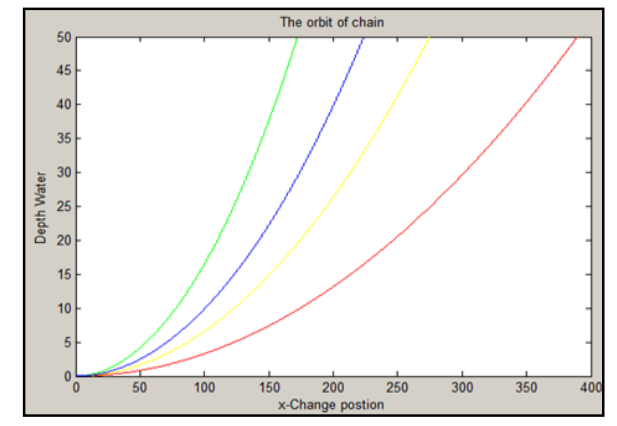

Figure. 11. Behavior of catenary following the horizontal distance when it is affected by different horizontal loads $\left(\mathrm{w}_{\mathrm{d}}=50 \mathrm{~m}, \mathrm{~d}=\right.$ $120 \mathrm{~mm})$

\section{CONCLUSIONS}

The parameters given by the authors have a close relation with each other. When $w_{d}$ changes, $S_{a b}$ is the most affected parameter. It can be seen that $\mathrm{w}_{\mathrm{d}}$ increases to $130 \mathrm{~m}$, the initial assumed chain length is not sufficient to anchor the vessel. The length needs to increase to $700 \mathrm{~m}$ or more in this case. Meanwhile, $\mathrm{T}_{\mathrm{b}}$ at the depth of $150 \mathrm{~m}$ is still working fine $\left(\mathrm{T}_{\mathrm{b}}<\mathrm{T}_{\text {break }}\right.$ of 1220.267T); thus, the initial diameter of catenary satisfies the working conditions. When $\mathrm{w}_{\mathrm{d}}$ is fixed and $\mathrm{W}_{\mathrm{s}}$ varies, it is clearly that the rise in $\mathrm{ws}_{\mathrm{s}}$ leads to the fall in $S_{a b}$ and $x_{a b}$ in comparison with the surge of $T_{b}$. The more increase in depth, the more different the parameters are from the others.
From the above relationship, it is noticeable that if the depth parameter changes, most of the other parameters will be affected, especially $S_{a b}$, which does not satisfy the initial assumption. Therefore, we should consider $S_{a b}$ in working environment to assure work requirements and wasting. For FPSO Ruby Princess working at a depth of $50 \mathrm{~m}$, the required length of catenary is about $400-500 \mathrm{~m}$.

In this paper, the authors only analyze in term of a specific procedure, so as if, the actual chain length is less than the computed. Therefore, we should study more and more to increase or decrease the length to the optimal and the most economical one. Besides, according to the general procedure ${ }^{11}$, we can perform 
the loop to choose the vertical load at the anchor. Then the tension at buoy is computed again in order to strengthen the test for catenary. This issue will be presented specifically in the later article.
These parameters are interdependent. Hence, as we contemplate the change in any parameter, should consider the relationship between them in order that the system Buoy - Chain - Anchor works stable and safe.

\section{Phân tích và mô phỏng hệ thống phao neo đơn}

- Lê Xuân Quang

- Võ Hiển

- Nguyễn Hữu Huy

Trường Đại học Giao thông vận tải Thành phố Hồ Chí Minh

- Trần Lý Minh Nhật

- Nguyễn Toàn Thắng

- Đỗ Quang Khánh

- Nguyễn Tường Long

Trường Đại học Bách Khoa, ĐHQG-HCM

\section{TÓM TÁT:}

Phao neo đơn (SPM) được sưr dụng phổ biến cho các kết cấu nổi FPSO (The floating production, storage and offloading) ở vùng biển thềm lục địa Việt Nam. Tuy nhiên ở nước ta vẫn thiếu các chỉ dẫn kỹ thuật và tiêu chuẩn liên quan để phân tích, mô phỏng và thiết kế hệ thống SPM. Đề tài này nhằm mục đích đề xuất quy trình xác định ảnh hưởng của tải trọng môi trường lên hệ thống SPM.

Từ khóa: Phao neo đơn, xích neo, SPM.

\section{TÀI LIỆU THAM KHẢO}

[1]. J. P. JonesNaval Facilities Engineering Command - Fleet Moorings, Basic Criteria and Planning Guidelines, Design Manual 26.5, June 1985.

[2]. Nguyen Tuong Long, Nguyen Huu Huy, et al., Calculation of service-life for catenary anchor system of FPSO Ruby Princess, Ruby Field, Vungtau, Vietnam, Project: 2010-2012.

[3]. V.Q Tran, K.A.T Truong. "Calculation and Simulation Chain - Buoy - Tanker"'(Single Point Mooring) by Analytical Method and Ansys Aqwa

Cụ thể là với quy trình này có thể xác định được chính xác vị trí cân bằng tổng mô-men của FPSO và lực ngang lớn nhất tác dụng lên SPM. Từ đó với thông số độ sâu nước xác định có thể tối ưu hóa chiều dài và đường kính xích mong muốn. Đề tài trình bày những mô phỏng căn bản của hệ thống xích khi thay đổi chiều sâu nước.

Program. Thesis, Ho Chi Minh City University of Technology, Vietnam, 2012.

[4]. Q.H Nguyen, "Calculation of the mooring line structure with sinker", Science Technology Water Resources and Environment Magazine, No.41, 6/2013.

[5]. "Stud Link Anchor Chain", Available: http://atlantic-group.com/products/stud-linkanchor-chain/, [Accessed: Sep, 2014].

\section{Trang 54}


[6]. Brian Hahn, D.T. Valentine, Essential Matlab for Engineers and Scientists, Third edition, Oxford, UK, 2007. 